University of Nebraska - Lincoln

DigitalCommons@University of Nebraska - Lincoln

June 2004

Network Consequences Due to Oligopolists and Oligopsonists in the Hog Industry, Pollution from Hog Production, and the Failure to Regulate Ecological Criteria

F. Gregory Hayden

University of Nebraska - Lincoln, ghayden1@unl.edu

Follow this and additional works at: https://digitalcommons.unl.edu/cbafacpub

Part of the Business Commons

Hayden, F. Gregory, "Network Consequences Due to Oligopolists and Oligopsonists in the Hog Industry, Pollution from Hog Production, and the Failure to Regulate Ecological Criteria" (2004). College of Business Faculty Publications. 12.

https://digitalcommons.unl.edu/cbafacpub/12

This Article is brought to you for free and open access by the Business, College of at DigitalCommons@University of Nebraska - Lincoln. It has been accepted for inclusion in College of Business Faculty Publications by an authorized administrator of DigitalCommons@University of Nebraska - Lincoln. 


\title{
Network Consequences Due to Oligopolists and Oligopsonists in the Hog Industry, Pollution from Hog Production, and the Failure to Regulate Ecological Criteria
}

\author{
F. Gregory Hayden
}

Humans have been in a symbiotic relationship with hogs since the time humans became a species. That relationship evolved into a set of transactional (as defined by instrumentalists) processes beginning with the hunter-gatherer tribes. The network of relationships has continued to become more numerous, intense, and complex. Hogs have served in social systems with humans as societal symbols for prowess for numerous groups (with wild boars, for example, on coats of arms in Europe), as religious symbols (both positive and negative), as a source of human disease in the hog-chicken-human cycle for generating flu in Asia, and, more recently, as a source of organs to be transplanted into humans. We usually think of the hog as a proven converter of waste material and low-cost crops into human food and leather. That use of hogs-which has become an inefficient system-is the area of concern here.

This analysis is based on the transactional network of institutional economics, as outlined in figure 1 . The purpose is threefold. The first is to review the model of the relationship between the oligopsonistic corporations which slaughter hogs and the farmer-feeder hog producer. The second is to further develop the normative theoretical connection between ecological systems and social institutions $\left(\mathrm{N}_{\mathrm{E}}\right.$ in figure 1). Most analysis in ecological economics has concentrated on the impact of socioeconomic institutions on the ecological system. The analysis here emphasizes the delivery of ecological criteria $\left(\mathrm{N}_{\mathrm{E}}\right)$ to institutional organizations from the ecology. Glen Atkinson has emphasized the importance of investigations of real world problems for improving the theoretical base of the institutionalist paradigm $(2003,5)$. That is a purpose here with regard to

The author is Professor of Economics at the University of Nebraska-Lincoln, USA. This paper was presented at the annual meeting of the Association for Evolutionary Economics at the Allied Social Science Association meetings, San Diego, California, January 3-5, 2004. 
Figure 1. Integrated Systems Model of Institutional Economics

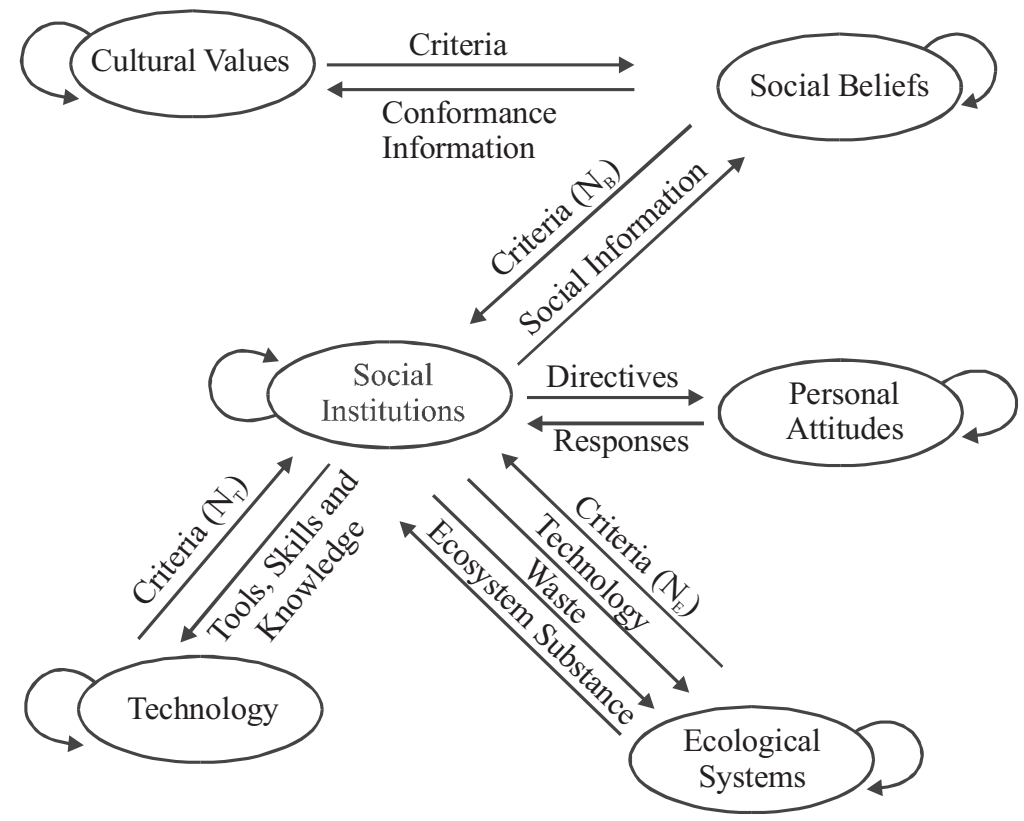

Source: Hayden in Tool and Bush 2003

$\mathrm{N}_{\mathrm{E}}$. The third purpose is to draw policy conclusions about the relationship between the pollution created by the concentrated hog confinement systems of oligopolistic pork processors and the concentrated ownership of the hog production system.

\section{Concentration in the Hands of a Few Corporations}

Recently, issues regarding hog production have been controversial in political and judicial arenas in many parts of the world. The most controversial issues have been about how to (1) control the corporate power of pork packers so that packers do not continue to destroy farm-based hog production with prices that are exploitative and too low to cover production costs, (2) prevent the ecological pollution and human health problems created by the large concentrated hog production centers owned by oligopolists, and (3) allow local communities to "zone out" large concentrated hog producers in order to prevent odor, disease, and ecological damage in the local area. After numerous legislative efforts and court decisions, there has been little success.

Thorstein Veblen explained in his Theory of Business Enterprise that the outcome of production processes that are conducted for pecuniary gain has been to disassociate the 
interests and decisions of business managers from the interests of the community and from productive efficiency. Current corporate hog production and slaughter systems are a confirmation of Veblen's thesis. The current corporate system (1) led to the destruction of farmer feeders due to unequal bargaining positions in the hog market between buyers who are oligopsonists and farmers, (2) implements technology that leads to serious pollution and disease problems, and (3) provides rural communities with low incomes and social problems. Thus, the overarching issue has been the design of production technology that allows for the concentration of ownership and control rather than for community welfare. The concentration engenders large profits that in turn provide for further empire building through investment, acquisition, and political power. Institutionalists have followed Veblen's lead to establish a literature that well defines the functioning of cooperative oligopolies. That literature is taken as given and need not be reviewed here.

The price exploitation of farmers can be simply explained with the two graphs in figure 2. On the left (graph $\mathrm{A}$ ) is the firm of a farmer feeder with limited production in a competitive setting in which each producer is a price taker. Figure 2 demonstrates the price situation for recent years with price $\mathrm{P}_{1}$. Since it is below the cost of production, large numbers of small producers have been destroyed. The price for fat hogs is dictated by oligopsonistic slaughter firms in an industry in which a few firms do most of the hog slaughtering in the United States. Graph A of figure 2 depicts the expected profit and output position of a hog farmer if the price is $\mathrm{P}_{2}$, which would be dictated to the farmer. In that situation, the price is below the productivity (MRP) of the hogs in the slaughter process at point a of graph B. Thus, farmers are exploited an amount equal to the area abcd because they sell to oligopsonists. The ability of farmer feeders to stay in business was destroyed by the increase in hog supply to $\mathrm{S}_{2}$. This was accomplished by (1) packers

Figure 2. Competitive Hog Farmer and Oligopsonistic Pork Packer

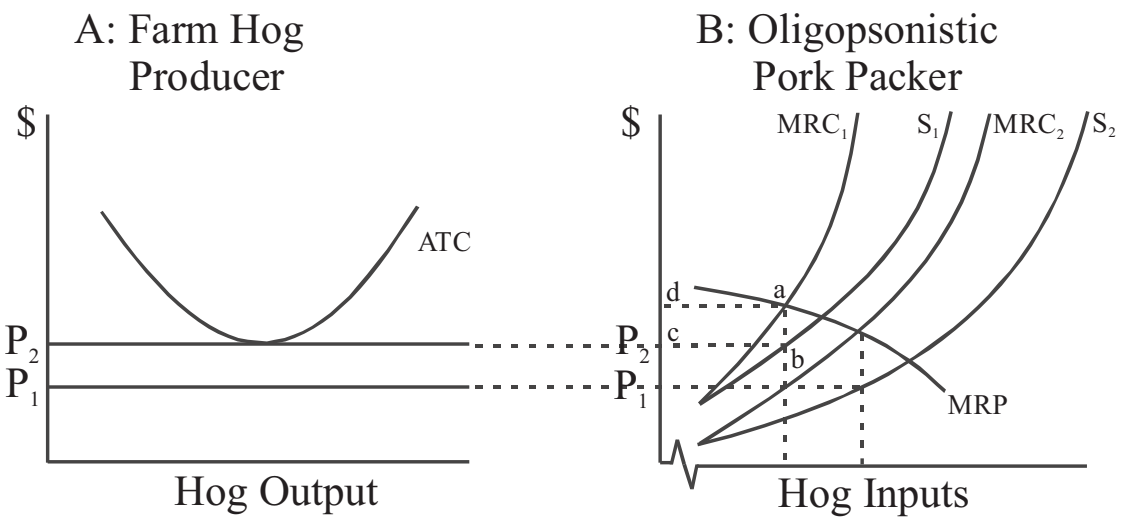


producing their own hogs that were used to push down hog prices ${ }^{1}$ and (2) the growth of other large oligopolistic hog producers. ${ }^{2}$ With the supply increased to $\mathrm{S}_{2}$, hog prices are below the farmer's cost of production, indicated by $\mathrm{P}_{1}$. The oligopolistic hog factories are able to send hogs to market at a lower monetary cost than farmers because the technology utilized in the large hog confinement unit is designed to increase cost and spread the costs of disease and pollution to the community and ecological systems. ${ }^{3}$

\section{Institutions and Ecological Criteria}

Institutions change ecological entities into tools to be used in the tool-skill-knowledge combinations known as technology. Although ecological components are taken from the ecology, they still contain qualities that are heeded and utilized as normative criteria $\left(\mathrm{N}_{\mathrm{E}}\right.$ in figure 1$)$ for the ongoing evaluation necessary to maintain socioeconomic processes. For example, different kinds of wood taken from the forest bring different requirements for preservatives to protect the lumber. As another example, recently maize was genetically engineered to produce a pig vaccine. A problem with the maize containing the vaccine is caused by a biological attribute of the maize that accompanied maize in its transition from the ecology-that is, the attribute of pollination. Cross-pollination has occurred in the system to contaminate other crops grown for food (New Scientist 2003, 15). The use of any set of ecological components in a social process requires numerous criteria from the natural world that must be included and heeded. That reality has usually been ignored in social sciences modeling and in policy making with regard to ecological components. As normative criteria are enforced, there is a submission of all forms of institutional life to the sovereignty of the criteria, whether the criteria are social, technological, or ecological. Although hogs were taken from nature to become a tool in a technological combination, they came as a genetic package that must be considered as primary data in making judgments about production processes.

Unfortunately, most social scientists have treated the ecology as even more quiescent and tranquil than James Swaney has stated (2003). Most theories emphasize the impact of institutions such as hog factories on the ecology, but not the impact of ecological entities on institutions. Natural attributes are tightly networked into every production process. ${ }^{4}$ Furthermore, natural attributes are powerful and can, in conjunction with production institutions, concoct a dangerous brew if the system selects and enforces inappropriate ecological criteria. Integrated systems are the result of numerous criteria being applied that are consistent with and necessary for the processing of the systems. Evaluative procedures are imposed upon systems through outside regulations or because the norms evolve to form part of system intelligence as a result of ongoing evaluation and decision making. As the normative intelligence evolves, production systems gain ecological norms that are enforced to provide particular results. 


\section{Ecological Criteria and the Problems of Hog Production}

Because ecological criteria have not been correctly formulated in the planning and regulation of hog production centers (in which thousands of hogs are concentrated in confined facilities), adverse impacts have developed for the quality of the environment, to include the health of humans and hogs. Long ago, the importance of normative criteria from social beliefs was recognized in the social sciences; more recently, the same has been the case for normative criteria from technology. The importance of normative criteria delivered from the ecosystem to social institutions, however, has not been recognized in the social sciences for modeling systems and policy.

Problems are not the consequence of the action of one agent as an entity acting in isolation. They are the result of multidimensional deliveries (see figure 1) among numerous agents and entities acting according to system criteria and rules. John Dewey emphasized that the activity of components is the result of activity over and across the distinct components (Dewey and Bentley [1949] 1973, 203). How their respective activities are guided depends on the normative criteria. Given the deliveries of the distinct (not separate) components to each other, the transactional process operates to "maintain the conditions of its own maintenance" (Dewey [1911] 1978, 467) through system norms. Making normative judgments for the system to produce the kind and quality of pollution delivered requires that a set of activities operate in conjunction with the criteria delivered by the ecosystem. This can be clarified with a review of problems associated with confinement hog production such as antimicrobial resistance and air, land, and water pollution. The review is not to explain particular problems in their detailed scientific complexity but rather to demonstrate how problems are created because of the way ecological criteria have been utilized in the hog industry. ${ }^{5}$

\section{Feeding Antibiotics and Antimicrobial Resistance}

Large confinement hog factories maintain a pecuniary cost advantage over farm swine production, in part due to the continuous use of antibiotics. The concentration of hogs into small areas creates stress and unsanitary conditions that encourage disease and allows for low-cost labor to be substituted for the management costs necessary to manage the more complex and diversified production on the farm. Antibiotic use is a substitute for management effort. Producers who obtain the greatest benefit from antibiotics are those who use antibiotics as a substitute for disease control practices (Secchi and Babcock 2002, 1281). Antibiotics are used in hog factories at a therapeutic level to treat sick hogs and at a subtherapeutic level for all hogs. Subtherapeutic levels are added to feed and water on a continuous basis to allow for early weaning of piglets, prevent disease, and promote growth. The long-term subtherapeutic doses diminish the effectiveness of antimicrobial therapy in humans and animals because the antibiotics contribute to the accelerated development of antibiotic resistance in bacteria. Bacteria move 
among ecosystems, hogs, and humans. In addition, resistance genes of the bacteria can be transferred to bacteria that are normally human specific. Resistant bacteria are found in human feces due to pork consumption and in waterways from hog-factory waste because a large percentage of antibiotics used are excreted unaltered in swine feces. "Although antimicrobial resistance has traditionally been viewed as a problem of the treatment (or treatment failure) of an individual patient in a given clinical setting, it is actually an ecological problem.... Growing evidence indicates that, with respect to the resistance problem, the 2 most important aspects of the host-commensal ecosystem are (1) that it can serve as a relatively stable reservoir of resistance microorganisms (including potentially pathogenic ones) long after cessation of antimicrobial treatment, and (2) that host microorganisms are continually being reinoculated by microorganisms from their environments" (Summers 2002, 585).

\section{Air Pollution}

Air pollution from the hog factories includes hydrogen sulfide, ammonia, pathogenic bacteria, carbon monoxide and dioxide, organic dust, endotoxins, and methane. Air pollutants from the facilities include about 160 volatile components. These, in turn, lead to disease problems for workers in the factories and residents of communities near the hog factories. The hydrogen sulfide is particularly dangerous for workers but also places neighboring residents at risk. Workers and residents living in the vicinity suffer from increased respiratory problems, headaches, diarrhea, fatigue, runny nose, sore throat, excessive coughing, burning eyes, and psychological dysfunction. This air pollution also decreases property values of neighbors.

\section{Land Pollution}

Because there are fewer swine production centers with higher concentrations of animals, the millions of tons of manure they produce is being sprayed and spread on smaller tracts of land. This is the base for many other problems, such as the spread of antibiotic-resistant bacteria and antibiotics into the ecosystem, air pollution, and the pollution of lakes, streams, and rivers. The land ecology itself is also harmed. Concentrated pit waste kills vegetation on the soil and species in the soil-both of which are no longer available to filter the runoff that goes into the water system.

There is severe competition for land near the hog factories for spreading the manure. In addition, there is severe financial pressure to place too much manure on the soil because the closer the land for disposal, the lower the transportation costs. Other added expenses include special equipment needed for land disposal of the manure such as pumps and nozzles to spray it in forests and on cropland, equipment to keep it in the soil to attempt to prevent erosion, berms built to prevent runoff, constructed wetlands when available cropland and forest area are insufficient, and so forth. When hog pro- 
duction is spread across the countryside on farms, the manure per acre of land is small and becomes an asset as a fertilizer without the need for expensive equipment and special construction.

\section{Water Pollution}

The quantity of manure from large individual hog factories can be greater than the sewage from major cities, yet the factories operate without a sewage system. They also operate without government inspection, measurement, or monitoring despite known environmental problems. The usual system is for the manure to first be stored in open air lagoons (open cesspools) which, even with clay liners, allow waste to leak into the surface water and ground water. The open air lagoons make a significant contribution to nitrogen pollution and ground water contamination. Nitrogen and phosphorus are released from the manure into the air, and the manure washes from fields into rivers, streams, estuaries, and oceans. Most of the nitrogen goes into the air and returns to land and water via rain as ammonia. Ammonia from rain and the waste that is spread or sprayed onto the soil converts to nitrates and is ready for runoff or leaching from the soil into waterways. The phosphorus from waste applied to soil is in excess of crop needs and is swept into water bodies through runoff. The system also spreads the heavy metals that become concentrated in the lagoons.

The results of the water pollution are water too contaminated for safe human consumption; fish kills in streams and rivers; and entrophication in estuaries, bays, and coastal ecosystems due to the loading of nutrients and organic matter in the water. These dead zones continue to grow due to contamination from non-point sources such as hog production.

\section{Policy Conclusions}

Oligopsonistic pork-slaughter corporations are also oligopolistic hog producers; thus, they can manipulate hog supply to keep hog prices below a break even price for farm producers, and, as a result, farm-based hog producers have gone out of business at a rapid rate. The technology used by the oligopolistic hog producers creates new pecuniary costs such as expensive buildings and equipment, construction of open waste lagoons, and the transportation and distribution of waste, in addition to new health and ecological costs. Some of the new oligopsolistic costs (which do not exist at all in farm-based hog systems) are not covered by market prices. Therefore, we can decrease the oligopolistic hold on the industry by increasing common-property protection of our land, air, soil, and antimicrobial therapy. The best way to break up the oligopolistic power, reduce the cost of production, restore hog production to farmers, increase the efficiency of hog production, and increase common-property protection is to ban the use of subtherapeutic use of antibiotics, which farm-based producers do not need, and 
effectively regulate environmental pollution, which is not a problem with small producers. The large hog factories cannot compete if they have to cover their excessive costs. These policies will increase market price (see $\mathrm{P}_{2}$ in figure 2), move hog production back to decentralized family farms, protect the effectiveness of antibiotics, and protect the environment in general. Furthermore, these policies are consistent with being able to create a public, as Dewey stressed was necessary for conjoint action ([1927] 1954, 137), among farmers, environmentalists, the judicial system, and community residents that will allow the integrated whole to effectively implement the policies.

\section{Notes}

1. Smithfield Foods, Inc. recently acquired Farmland Foods' pork-processing division, making Smithfield the largest pork processor in the United States, with about one-third of total production. In addition, Smithfield is number one in hog production.

2. An example of relationships among oligopolists can be seen in a recent purchase by Smithfield. Smithfield recently acquired Vall Companies, Inc. operations from Vall's Spanish parent company, Vall Companies Group. Vall Companies, Inc. in Oklahoma and Texas own 20,000 sows that produce 350,000 market hogs per year. Their production is sold under contract to another major oligopolist in the industry, Seaboard Corp.

3. These findings indicate a need to consider Harry Trebing's theory about technology and corporate concentration in the telecommunications industry as a more general hypothesis. Economists have suggested that Schumpeterian "creative gales of destruction" from technological change and innovation will eliminate monopolistic tendencies and market power. "Trebing has treated such conclusions with considerable suspicion. In fact, the dynamics of technological change may even strengthen the market power for key players in the industry" (Javary and Mansell 2002, 164). Trebing based his observations on empirical research of the telecommunications industry. Javary and Mansell found the same to be the case with the Internet service provider industry in the United Kingdom. It is also true of hog production. Even though technological innovations in hog production are less efficient than the technology replaced, the new innovations have been utilized to concentrate production into fewer and fewer corporations.

4. Economists have begun to complicate production functions toward reality in order to account for joint products like water and air pollution that accompany the production of goods and services. However, the literature surveyed does not provide for a production function of ecological attributes as an input-not in abstract methodological discussions and not in applied work.

5. The best source found for references about medical and scientific studies and publications regarding the use of antibiotics and other health problems associated with hog production is the Medline Web site at http://gateway1.ma.ovid.com/ovidweb.cgi.

\section{References}

Atkinson, Glen. "Editor's Note.” Journal of Economic Issues 37 (March 2003): 1-5.

Dewey, John. "Contribution to a Cyclopedia of Education." In John Dewey: The Middle Works, vol. 6, edited by J.

A. Boydston. 1911. Reprint, Carbondale: Southern Illinois University, 1978.

The Public and Its Problems. 1927. Reprint, Chicago: Swallow Press, 1954. 
Dewey, John, and Arthur F. Bentley. "Knowing and the Known." In Useful Procedures of Inquiry, edited by Rollo Handy and E. C. Harwood. 1949. Reprint, Great Barrington, Mass.: Behavioral Research Council, 1973.

Hayden, F. Gregory. "Policy Concerns Regarding Ecologically Sound Disposal of Industrial Waste Materials." In Institutional Analysis and Economic Policy, edited by Marc R. Tool and Paul Dale Bush. Boston: Kluwer Academic Publishers, 2003, 461-492.

Javary, Michèle, and Robin Mansell. "Emerging Internet Oligopolies: A Political Economy Analysis." In The Institutionalist Approach to Public Utilities Regulation, edited by Edythe S. Miller and Warren Samuels. East Lansing, Mich.: Michigan State University Press, 2002, 162-201.

New Scientist. “Tougher Laws on Pharm Crops 'Not Tough Enough.” March 22, 2003.

Secchi, Silva, and Bruce Babcock. "Pearls before Swine? Potential Trade-Offs between the Human and Animal Use of Antibiotics." American Journal of Agricultural Economics 84 (November 2002): 279-1286.

Swaney, James. "Are Democracy and Common Property Possible on Our Small Earth?” Journal of Economic Issues 37 (June 2003): 261-290.

Summers, Anne O. "Generally Overlooked Fundamentals of Bacterial Genetics and Ecology." Clinical Infectious Diseases 34 (September 2002): 85-92. 